\title{
Potensi Penyimpanan Serbuk Sari dalam Produksi Benih Hibrida Mentimun (Cucumis sativus L) Varietas KE014
}

\author{
The potential of pollen storage in hybrid seed production of cucumber (Cucumis sativus L.) \\ Variety KE014
}

\author{
Ekowati Nursiam Harliani ${ }^{1}$, Endah Retno Palupi ${ }^{1 *}$, dan Dudin Supti Wahyudin ${ }^{2}$
}

Diterima 4 Maret 2014/Disetujui 21 Juli 2014

\begin{abstract}
High pollen viability with adequate quantity determine yield of hybrid seed production. Stored pollen with high viability is expected to produce high quantity and quality of hybrid seed. The aims of this research was to study the possibility of using stored pollen in hybrid seed production of cucumber (Cucumis sativus L.). The research was conducted in Pollen Laboratory, screen house $(\mathrm{SH})$, and experimental station of PT. East West Seed Indonesia, Gumuk Segawe village, Ajung subdistrict, Jember, East Java from March until August 2011. The research was started with observation on the timing of receptive stigma based on color changes of petal and stigmatic surface every hour during which time pollination was also conducted. Percentage of fruit set and seed set from each pollination were observed. The research was then continued with experiments conducted in the field and SH separately. The experiment was arranged in completely randomized block design with 10 treatments in the field and 13 treatments in SH. The treatments for field experiment were combination of storage period $(0,20,30$ and $40 \mathrm{DAS})$ and pollination technique $(1,2,3$ times swabbing). The storage period for SH experiment were 0, 7, 14 and 28 DAS. The treatments were repeated 3 times. The result showed that the stigma was receptive during 07.00-13.00 h. The viability of stored pollen 20-40 DAS ranged between 0.8-4\% whereas 7-28 DAS ranged between 4.8$9.71 \%$. Fruit set from stored pollen ranged $21.23-42.42 \%$ and seed set ranged $16.89-25.26 \%$ in the field compared to use of fresh pollen 54.64 and $59.26 \%$ respectively. As for SH the fruit set ranged $30.69-63.98 \%$ and seed set ranged $18.22-35.68 \%$ from stored pollen compared $73.56 \%$ and $80.69 \%$ from fresh pollen. Reproductive succes of stored pollen in the field ranged 12.82-29.29\% with averaged of $19.89 \%$ compared to that of fresh pollen, whereas in the SH used of stored pollen resulted in 10.60-25.29\%, averaged $18.89 \%$ reproductive succes.
\end{abstract}

Key words: empty seed, pollen viability, seed set, seed quality, stigma receptivity

\begin{abstract}
ABSTRAK
Viabilitas serbuk sari yang tinggi dan jumlah serbuk sari yang memadai menentukan produksi benih hibrida mentimun. Serbuk sari yang telah disimpan dan mempunyai viabilitas yang tinggi diharapkan dapat digunakan dalam produksi benih hibrida dengan mutu yang tinggi. Oleh sebab itu penelitian ini bertujuan untuk mempelajari kemungkinan pemanfaatan serbuk sari yang telah disimpan dalam produksi benih hibrida mentimun (Cucumis sativus L.). Penelitian ini dilakukan di Laboratorium Serbuk Sari, screen house (SH) dan lahan percobaan Production Farm PT. East West Seed Indonesia, Desa Gumuk Segawe, Kecamatan Ajung, Kabupaten Jember, Jawa Timur dari bulan Maret hingga Agustus 2011. Penelitian ini diawali dengan penentuan masa reseptif stigma yang diamati berdasarkan perubahan warna mahkota dan permukaan stigma setiap jam, dan pada saat yang sama stigma diserbuk. Pengamatan dilakukan terhadap pembentukan buah dan benih. Penelitian dilanjutkan dengan pemanfaatan serbuk sari yang telah disimpan untuk produksi benih hibrida mentimun di lapang dan SH secara terpisah pada waktu yang berbeda. Rancangan penelitian
\end{abstract}

\footnotetext{
${ }^{1}$ Departemen Agronomi dan Hortikultura, Fakultas Pertanian, Institut Pertanian Bogor

(Bogor Agricultural University), Jl. Meranti, Kampus IPB Darmaga, Bogor 16680, Indonesia

Telp.\&Faks.62-251-8629353. e-mail erpalupi@yahoo.co.id (*penulis korespondensi)

${ }^{2}$ PT East West Seed Indonesia,Desa Benteng, Kecamatan Campaka, Purwakarta, Jawa Barat 41181, Indonesia
} 
yang digunakan RKLT dengan 10 perlakuan (percobaan di lapang) dan 13 perlakuan (percobaan di SH), perlakuan yaitu kombinasi antara lama simpan serbuk sari dan teknik penyerbukan. Perlakuan pada percobaan di lapang adalah kombinasi lama simpan $(0,20,30$ dan 40 HSS $)$ dan teknik penyerbukan (1, 2 dan 3 kali usapan kuas), sementara serbuk sari untuk percobaan di SH (0, 7, 14, 21, dan 28 HSS). Masing-masing kombinasi perlakuan diulang sebanyak 3 kali. Hasil pengamatan menunjukkan bahwa masa reseptif stigma tanaman betina mentimun varietas KE014 terjadi antara pukul 07.00-13.00. Serbuk sari yang telah disimpan antara 20-40 HSS mempunyai viabilitas sekitar antara $0.80-4.05 \%$, sementara 7-28 HSS sekitar 4.86-9.71\%. Pembentukan buah dan benih di lapang masing-masing berkisar $21.23-42.42 \%$ dan 16.89-25.26\% dibandingkan dengan menggunakan serbuk sari segar sebesar 54. 64\% dan 59.26\%. Pembentukan buah dan benih pada penelitian di SH masing-masing berkisar $30.69-63.98 \%$ dan $18.22-35.68 \%$ dibandingkan dengan menggunakan serbuk sari segar sebesar $73.56 \%$ dan $80.69 \%$. Keberhasilan reproduksi dari penggunaan serbuk sari yang telah disimpan pada penelitian di lapangan berkisar 12.82-29.29\% dari kontrol dengan rata-rata sebesar $19.89 \%$. Potensi keberhasilan reproduksi di SH sebesar $10.60-25.29 \%$ dengan rata-rata sebesar $18.89 \%$.

Kata kunci: benih hampa, mutu benih, pembentukan benih, reseptif stigma, viabilitas serbuk sari

\section{PENDAHULUAN}

Mentimun merupakan salah satu komoditi sayuran dalam bentuk buah yang penting di Indonesia setelah tomat dan terong. Buah mentimun dan gherkin yang belum matang banyak digunakan sebagai sayuran dan dibuat acar, asinan, kimchi, salad dan lalap. Mentimun dapat pula dikonsumsi sebagai minuman segar atau jus. Produksi mentimun tahun 2008 sebesar 540122 ton dan meningkat tahun 2009 menjadi 583139 ton, meningkat sebesar 8\%. Namun pada tahun 2010 dan 2011 terjadi penurunan produksi, masing-masing sebesar $6.2 \%$ dan $3.7 \%$ dari tahun sebelumnya (BPS, 2011).

Peningkatan produksi dapat dilakukan salah satunya dengan penggunaan benih hibrida yang mempunyai produktivitas tinggi. Benih hibrida famili Cucurbitaceae umumnya diproduksi melalui penyerbukan manual menggunakan serbuk sari dari bunga segar, sehingga tetua jantan dan betina harus ditanam bersamaan dengan rasio 1:3. Jika produksi benih hibrida dilakukan dengan pola kerjasama dengan petani, maka tetua jantan tidak harus ditanam bersamaan. Untuk kebutuhan penyerbukan disediakan serbuk sari yang sudah diproduksi dan disimpan sebelumnya, sehingga efisiensi penggunaan lahan meningkat. Dengan demikian kualitas dan ketersediaan serbuk sari harus terjamin untuk keberhasilan produksi benih hibrida. Kualitas serbuk sari dapat dilihat dari viabilitasnya (Kelly et al., 2002). Serbuk sari dengan viabilitas tinggi akan lebih dulu membuahi sel telur dan menghasilkan benih bermutu tinggi. Oleh karena itu dalam produksi benih diperlukan serbuk sari dengan viabilitas tinggi dan dalam jumlah yang memadai.

Kendala utama pada proses produksi benih hibrida Cucurbitaceae adalah ketersediaan serbuk sari dengan viabilitas yang tinggi. Secara alami viabilitas serbuk sari hanya dapat dipertahankan selama satu hari. Penelitian Neppi dan Pacini (1993) menunjukkan viabilitas serbuk sari bunga jantan Cucurbita pepo yang masih kuncup sebesar $75 \%$, pada saat bunga mekar meningkat sebesar 92\%, kemudian viabilitasnya terus menurun setelah bunga anthesis, dan hanya tinggal sebesar $10 \%$ pada satu hari setelah anthesis. Zaman (2006) menyatakan bahwa viabilitas serbuk sari mentimun dari bunga segar berkisar antara 96.2-97.8\%, pada melon 88.2-97.7\% dan pada semangka $94.7-95 \%$. Agbagwa et al. (2007) melaporkan bahwa viabilitas serbuk sari Cucurbita moschata pada saat bunga mekar sekitar $90 \%$ dan terus berkurang menjadi $62 \%$ saat bunga hampir layu dan hanya tinggal $8 \%$ pada satu hari setelah anthesis. Karakteristik fisik yang lengket pada kebanyakan serbuk sari tanaman famili Cucurbitaceae diduga menjadi faktor cepat menurunnya viabilitas serbuk sari mentimun (Delephane dan Meyer, 2009). Oleh sebab itu penelitian penyimpanan serbuk sari untuk mempertahankan viabilitas serbuk sari Cucurbitaceae agar tetap tinggi sangat 
diperlukan untuk menjamin ketersediaan serbuk sari dalam produksi benih hibrida khususnya mentimun.

Pemanfaatan serbuk sari yang sudah disimpan dalam produksi benih hibrida mulai banyak digunakan terutama produsen benih skala besar. Sejak tahun 2000 di Brazil produksi benih terong hibrida F1 varietas CICA dilakukan dengan menggunakan serbuk sari yang telah disimpan pada suhu $5{ }^{\circ} \mathrm{C}$ selama 60 hari (Nascimento et al., 2009). Beberapa produksi benih hibrida F1 tomat di Taiwan menggunakan serbuk sari yang telah disimpan beberapa minggu pada wadah yang kering berisi calsium chloride dalam kulkas (Tay, 2013). Tujuan penelitian ini ialah menentukan waktu penyerbukan yang tepat untuk mentimun (Cucumis sativus $\mathrm{L}$.) varietas KE014 dan mempelajari potensi pemanfaatan serbuk sari yang telah disimpan dalam produksi benih hibrida varietas KE014.

\section{BAHAN DAN METODE}

Penelitian ini dilaksanakan pada bulan Maret 2011 sampai Agustus 2011 di lahan percobaan Production Farm PT. East West Seed Indonesia, Desa Gumuk Segawe, Kecamatan Ajung, Kabupaten Jember, Screen House (SH) dan Laboratorium Serbuk Sari PT. East West Seed Indonesia, Jember, Jawa Timur.

Bahan tanaman yang digunakan dalam penelitian ini adalah tanaman betina dan tanaman jantan mentimun (Cucumis sativus L.) varietas KE014. Bahan untuk pengujian daya berkecambah secara in vitro adalah media PGM F (Fariroh et al., 2011) yang terdiri atas $5 \mathrm{~g}$ sukrosa, $0.01 \mathrm{~g} \mathrm{H}_{3} \mathrm{BO}_{3}, 0.025 \mathrm{~g}$ $\mathrm{CaCl}_{2}, 0.032 \mathrm{~g} \mathrm{KH}_{2} \mathrm{PO}_{4}, 3$ g PEG 6000 dan 50 $\mathrm{ml}$ aquades.

Peralatan yang digunakan yaitu perlengkapan penyerbukan antara lain: kuas kecil, penyungkup dari bahan plastik dan kertas, pita kawat dan label. Mikroskop cahaya, deckglass, box, cryovial dan jarum ose digunakan untuk pengujian viabilitas serbuk sari. Alat yang digunakan untuk pengujian mutu benih mentimun antara lain germinator, oven, timbangan, desikator, dan kertas buram. Ruang simpan serbuk sari yang digunakan adalah ultra freezer.

\section{Percobaan I. Penentuan Masa Reseptif Stigma}

Penentuan masa reseptif stigma dilakukan di lapangan dan screen house. Pengamatan kualitatif dilakukan terhadap perubahan warna mahkota bunga dan warna permukaan stigma setiap jam dari pkl 07.0016.00 , bunga yang diamati sebanyak 3 bunga betina dari tanaman yang berbeda setiap jam pengamatan, sehingga total bunga yang diamati sebanyak 30 bunga betina. Pengamatan kuantitatif dilakukan terhadap persentase pembentukan buah dan benih dari penyerbukan pada waktu yang berbeda selama bunga mekar. Penyerbukan dilakukan pada 6 bunga betina setiap jam penyerbukan, sehingga total bunga yang diserbuk sebanyak 60 bunga betina. Waktu penyerbukan yang menghasilkan persentase pembentukan buah dan benih yang tinggi menunjukkan masa reseptif stigma. Persentase pembentukan benih dihitung berdasarkan proporsi biji bernas yang terbentuk terhadap jumlah ovul dalam satu bakal buah. Jumlah ovul dalam satu bakal buah merupakan rata-rata dari 30 bunga betina yang dihitung di bawah mikroskop.

\section{Percobaan 2. Perlakuan Kombinasi Lama Simpan Serbuk Sari dan Teknik Penyerbukan terhadap Pembentukan Buah dan Benih}

Penelitian ini dilakukan di dua lokasi, dengan materi yang berasal dari pertanaman di lapangan dan di screen house, karena pertumbuhan tanaman di lapangan kurang memuaskan. Pada masing-masing lokasi dilakukan dua tahap percobaan, yaitu pengamatan viabilitas serbuk sari selama penyimpanan dan pemanfaatan serbuk sari yang telah disimpan dalam produksi benih.

\section{Viabilitas Serbuk Sari Selama Penyim- panan}

Model rancangan yang digunakan adalah RAL (Rancangan Acak Lengkap) satu faktor yaitu lama simpan serbuk sari. Lot serbuk sari yang digunakan untuk penyerbukan di lapang berbeda dengan penyerbukan di screen house. Pada penyerbukan di lapangan digunakan serbuk sari dengan periode simpan 20, 30, dan 40 hari, sedangkan pada penyerbukan di screen house digunakan serbuk sari yang telah di simpan selama 7, 14, 
21 dan 28 hari. Percobaan pada masing masing lot serbuk sari di lapangan maupun screen house mengguna-kan bunga segar (kontrol) untuk pembanding pengujian viabilitas serbuk sari. Anther bunga segar yang sudah pecah diuji dengan mengeluarkan serbuk sari menggunakan pinset dan jarum ose.

Bunga jantan mentimun KE014 dipanen sehari sebelum anthesis (Fariroh et al., 2011) dibawa ke laboratorium, kemudian anthera dipisahkan dari bunga dan dikering-anginkan di ruang ber-AC dengan suhu $20-25{ }^{\circ} \mathrm{C}, \mathrm{RH}$ $60 \%$ selama 24 jam. Setelah anthera kering, serbuk sari diekstrak dengan cara mengocok anthera melalui kain kasa. Serbuk sari yang diperoleh kemudian dikeringkan dalam boks yang berisi $\mathrm{MgCl}_{2}$ selama 24 jam, dimasukkan dalam cryovials dan disimpan dalam ultra freezer bersuhu $-79 \pm 2{ }^{\circ} \mathrm{C}$.

Sebelum digunakan untuk penyerbukan viabilitas serbuk sari diuji dengan mengecambahkannya dalam media PGM F. Serbuk sari yang telah disimpan dalam ultra freezer dikeluarkan dan diletakkan pada suhu ruang selama 30 menit, kemudian dikecambahkan. Setelah inkubasi selama 4 jam serbuk sari diamati menggunakan mikroskop. Pengecambahan diulang 6 kali (6 deckglass), dengan 4 bidang pandang pengamatan berbeda dalam satu ulangan. Serbuk sari dikategorikan berkecambah apabila panjang tabung sari $\geq$ diameter serbuk sari. Data dianalisis dengan menggunakan uji F. Jika berbeda nyata maka dilanjutkan dengan menggunakan uji lanjut DMRT pada taraf 0.05 .

\section{Pemanfaatan Serbuk Sari yang Telah Disimpan dalam Produksi Benih}

Model rancangan yang digunakan adalah RKLT (Rancangan Kelompok Lengkap Teracak) satu faktor yaitu perlakuan kombinasi lama simpan serbuk sari dan teknik penyerbukan. Pada lot serbuk sari pertanaman di lapangan lama simpan 20, 30, 40 hari setelah simpan (HSS) dikombinasikan dengan per-lakuan teknik penyerbukan yaitu 1, 2 dan 3 kali usapan kuas sehingga terdapat 9 perlakuan kombinasi lama simpan dan teknik penyerbukan, sedangkan pada pertanaman dalam screen house lama simpan 7, 14, 21, 28 HSS dikombinasikan dengan perlakuan teknik penyerbukan yaitu 1, 2, dan 3 kali usapan kuas sehingga terdapat 12 perlakuan kombinasi. Tiap perlakuan diulang sebanyak 3 kali.
Sebagai kontrol (0) digunakan metode yang dilakukan oleh petani EWSI yakni menyerbuki bunga betina dengan bunga jantan segar yang dipanen sehari sebelum mekar, yang keesokan hari anthernya sudah pecah. Penyerbukan menggunakan serbuk sari dari bunga segar (kontrol) dilakukan dengan cara mengusapkan anther ke stigma hingga serbuk sari yang di sekitar anther habis dan menutupi seluruh permukaan stigma, satu anther menyerbuki satu bunga betina. Agar tidak terkontaminasi oleh serbuk sari lain, bunga betina KE014 disungkup sebelum diserbuk.

Mahkota bunga yang sudah diserbuk diikat dengan kawat agar tidak dikunjungi serangga penyerbuk. Penyerbukan dilakukan selama 7 hari berturut-turut, karena bunga betina tidak mekar bersamaan. Tanaman betina KE014 dipelihara sesuai dengan standar budidaya perusahaan, setiap minggu dilakukan penjarangan agar kelembaban di sekitar tanaman terjaga. Buah mentimun KE014 dipanen pada saat masak fisiologis yaitu pada umur panen berkisar 55-65 hari setelah penyerbukan. Peubah yang diamati adalah:

1. Persentase pembentukan buah dihitung dengan rumus :

Persentase pembentukan buah $=$

$\frac{\sum \text { buah yang dipanen }}{\text { Sbakal buah yang diserbuk }} \times 100 \%$

2. Persentase pembentukan benih dihitung dengan rumus :

Persentase pembentukan benih $=$

$\frac{\sum \text { biji bernas }}{\sum \text { rata-rata ovul per bakal buah }} \times 100 \%$

3. Keberhasilan reproduksi (KR) dihitung dengan rumus :

$\mathrm{KR}=$ pembentukan buah (\%) $\mathrm{x}$ pembentukan benih (\%)

4. Penurunan keberhasilan reproduksi dihitung dengan rumus :

Penurunan keberhasilan reproduksi $=$ $\frac{\text { penurunan KR perlakuan }}{\text { penurunan KR kontrol }} \times 100 \%$

\section{Bobot 100 butir}

6. Potensi tumbuh maksimum (PTM): jumlah benih yang tumbuh menjadi kecambah normal maupun abnormal pada pengamatan terakhir dihitung dengan rumus: 
$\mathrm{PTM}=\frac{\sum \text { benih yang tumbuh }}{\text { total benih yang dikecambahkan }} \times$ $100 \%$

7. Daya berkecambah (DB): dengan menggunakan metode UKDdP yakni menghitung jumlah benih yang membentuk kecambah normal $(\mathrm{KN})$ pada pengamatan pertama dan kedua terhadap jumlah benih yang ditanam dihitung dengan rumus:

$\mathrm{DB}=\frac{K N I+K N I I}{\text { total benih yang dikecambahkan }} \mathrm{x}$
$100 \%$

8. Bobot kering kecambah normal (BKKN) dengan mengeringkan kecambah normal pada suhu $60{ }^{\circ} \mathrm{C}$ selama $3 \times 24$ jam.

Data dianalisis dengan menggunakan uji F dan jika berbeda nyata maka dilanjutkan dengan uji DMRT pada taraf 0.05. Analisis korelasi dilakukan untuk mengetahui hubungan antar karakter yang diamati, yaitu daya berkecambah serbuk sari, persentase pembentukan buah, pembentukan benih, dan bobot 100 butir.

\section{HASIL DAN PEMBAHASAN}

\section{Masa Reseptif Stigma}

Penyerbukan di lapangan dilakukan pada bulan April 2011 pada saat curah hujan tinggi (Tabel 1), karena sebagian bakal buah yang telah diserbuki membusuk, sehingga persentase pembentukan buah rendah. Oleh karena itu penelitian juga dilakukan di dalam screen house $(\mathrm{SH})$, untuk melindungi tanaman dari hujan serta untuk mempermudah pengendalian hama dan penyakit. Penyerbukan di screen house dilaksanakan pada bulan Juni 2011 ketika curah hujan sudah berkurang.

Pengamatan di lapangan pada pukul 07.00-09.00 menunjukkan bahwa ketika mekar, mahkota bunga betina berwarna kuning keemasan dengan permukaan stigma berwarna kuning kehijauan (Gambar 1a). Pada pukul 10.00-11.00 warna mahkota bunga dan permukaan stigma berwarna kuning (Gambar 1b). Warna mahkota dan permukaan stigma pada tanaman di lapangan akan terus memudar sekitar pukul 12.00-16.00 (Gambar 1c) seiring dengan berkurangnya sekresi yang dihasilkan. Berdasarkan pengamatan visual dengan perubahan warna mahkota bunga dan permukaan stigma makan masa reseptif stigma ditentukan sekitar 07.00-14.00.

Dalam SH bunga mekar dengan warna mahkota kuning keemasan pada pukul 07.0009.00 dan permukaan stigma berwarna kuning (Gambar 1b). Pada pukul 10.00-14.00 warna mahkota dan permukaan stigma berwarna kuning (Tabel 2). Pada tanaman dalam SH warna mahkota dan permukaan stigma belum memudar hingga pukul 16.00 (Tabel 2). Dengan melihat perbandingan warna mahkota dan permukaan stigma pada tanaman di lapangan maupun di $\mathrm{SH}$ maka dengan demikian masa reseptif stigma di lapangan lebih pendek (4 jam) daripada dalam SH (7 jam), diduga karena kelembaban udara dalam SH lebih stabil dan lebih tinggi dibandingkan di lapangan. Kelembaban yang tinggi dalam SH diduga dapat memperlambat penguapan sekresi pada permukaan stigma.

Tabel 1. Kondisi iklim pada saat pelaksanaan penelitian

\begin{tabular}{lcccccc}
\hline \multirow{2}{*}{ Bulan } & \multicolumn{2}{c}{ Suhu $\left({ }^{0} \mathrm{C}\right)$} & \multicolumn{2}{c}{$\mathrm{RH}(\%)$} & \multirow{2}{*}{$\mathrm{CH}(\mathrm{mm} / \mathrm{hari})$} & \multirow{2}{*}{$\mathrm{HH}$} \\
\cline { 2 - 5 } & Lapangan & $\mathrm{SH}$ & Lapangan & $\mathrm{SH}$ & & \\
\hline Februari & $26.6-33.5$ & - & $57.9-84.0$ & - & 179 & 15 \\
Maret & $26.2-32.0$ & - & $57.5-82.3$ & - & 117 & 22 \\
April & $26.2-38.4$ & - & $45.6-83.6$ & - & 122 & 18 \\
Mei & $26.3-39.7$ & 33.1 & $47.3-82.0$ & 69.4 & 98 & 11 \\
Juni & $25.1-31.7$ & 34.3 & $50.0-82.0$ & 66.5 & 8 & 4 \\
Juli & $24.3-31.7$ & 42.0 & $41.5-82.0$ & 45.0 & 14 & 4 \\
Agustus & - & 34.0 & - & 69.6 & - & - \\
\hline
\end{tabular}

Sumber: Data stasiun cuaca STTC PT. East West Seed Indonesia, Jember.

Keterangan: $\mathrm{CH}$ : curah hujan, HH: hari hujan, RH: kelembaban nisbi, SH: screen house.

- : tidak ada data lengkap 
Tabel 2. Perubahan warna mahkota dan permukaan stigma bunga betina mentimun di lapangan dan dalam screen house

\begin{tabular}{ccccc}
\hline \multirow{2}{*}{ Waktu } & \multicolumn{2}{c}{ Lapangan } & \multicolumn{2}{c}{ Screen house } \\
& Warna mahkota & $\begin{array}{c}\text { Warna permukaan } \\
\text { stigma }\end{array}$ & Warna mahkota & $\begin{array}{c}\text { Warna permukaan } \\
\text { stigma }\end{array}$ \\
\hline 07.00 & kuning keemasan & Kuning kehijauan & kuning keemasan & kuning \\
08.00 & kuning keemasan & kuning & kuning keemasan & kuning \\
09.00 & kuning keemasan & kuning & kuning keemasan & kuning \\
10.00 & kuning & kuning & kuning & kuning \\
11.00 & kuning & kuning & kuning & kuning \\
12.00 & kuning pucat & kuning & kuning & kuning \\
13.00 & kuning pucat & kuning pucat & kuning & kuning \\
14.00 & kuning pucat & kuning pucat & kuning & kuning \\
15.00 & kuning memudar & putih & kuning pucat & kuning pucat \\
16.00 & kuning memudar & putih & kuning pucat & kuning pucat \\
\hline
\end{tabular}

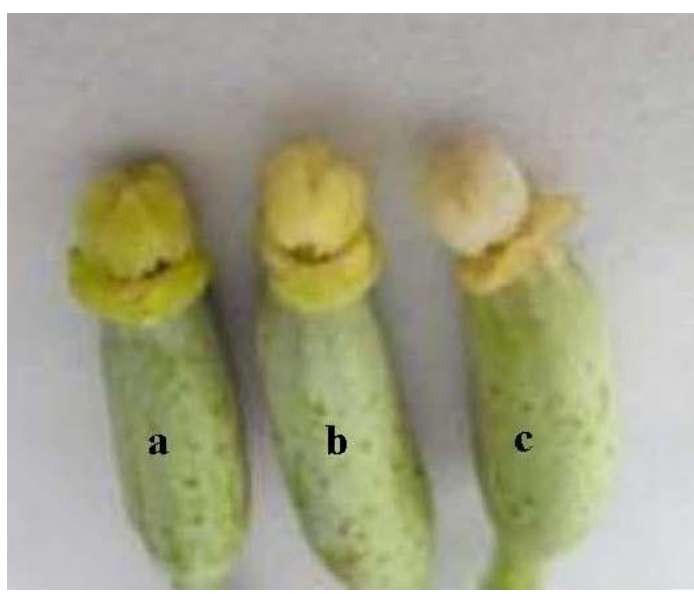

Gambar 1. Warna permukaan stigma pada bunga betina KE014: a. kuning kehijauan (07.00), b. kuning (08.00-14.00), c. putih (16.00layu)

Persentase pembentukan buah tertinggi di lapangan mencapai $83.3 \%$ dengan pola pembentukan buah di lapangan menunjukkan dua puncak yaitu pada pagi hari (pukul 08.00) dan siang hari (pukul 13.00). Pembentukan benih per buah tertinggi terjadi pada pukul 07.00 yaitu sebesar 398 butir/buah $(78.5 \%)$ (Tabel 3). Persentase pembentukan benih akan terus menurun hingga pukul 15.00 hanya sebesar 36.8\%. Sukma dan Setiawati (2010) menyatakan bahwa aplikasi pupuk daun pada sore hari akan meningkatkan persentase tanaman berbunga sampai 50\%.
Berdasarkan pengamatan visual pada bunga diketahui bahwa periode reseptif stigma di lapangan terjadi antara pukul 07.00-14.00, sedangkan berdasarkan pengamatan pembentukan buah dan benih terjadi antara pukul 07.00-13.00. Setelah pukul 13.00, persentase pembentukan buah < 40\%. Hal tersebut menyebabkan benih yang dihasilkan tidak masuk dalam standar produksi benih hibrida mentimun varietas KE014 di PT. East West Seed Indonesia (Supriyadi Juni 2011, komunikasi pribadi). Oleh sebab itu, diperkirakan waktu penyerbukan yang paling baik untuk tanaman KE014 yang ditanam di lapangan berkisar antara pukul 07.00-13.00. Namun demikian disarankan penyerbukan hanya sampai pukul 12.00 karena setelah tengah hari kondisi berawan dan kemungkinan turun hujan pada sore hari yang menyebabkan kegagalan penyerbukan.

Persentase pembentukan buah di SH mencapai $100 \%$ pada pukul $07.00,08.00$ dan 10.00 dengan pola pembentukan buah cenderung stabil dari pagi hingga tengah hari (pukul 14.00) kemudian menurun di sore hari. Pembentukan benih mempunyai pola yang serupa di dua lokasi pertanaman di lapangan maupun di $\mathrm{SH}$, yaitu cenderung tinggi bila penyerbukan dilakukan pada pagi hari (tertinggi 94.5\%) dan mulai menurun menjelang tengah hari (10.00-11.00) (Tabel 3). Hal ini diduga disebabkan suhu udara yang meningkat menjelang tengah hari sehingga viabilitas serbuk sari dan reseptivitas stigma menurun 
Tabel 3. Persentase pembentukan buah dan benih mentimun pada berbagai waktu penyerbukan di lapangan dan dalam screen house

\begin{tabular}{cccccc}
\hline $\begin{array}{c}\text { Waktu } \\
\text { Penyerbukan }\end{array}$ & $\begin{array}{c}\Sigma \text { Bunga } \\
\text { diserbuk }\end{array}$ & $\begin{array}{c}\Sigma \text { Buah (\%) } \\
\text { Lapangan }\end{array}$ & $\Sigma$ Benih/buah (\%) & $\begin{array}{c}\Sigma \text { Buah (\%) } \\
\text { Screen House }\end{array}$ \\
\hline 07.00 & 6 & $2(33.3)$ & $389.0(78.5)$ & $6(100)$ & $434.1(85.6)$ \\
08.00 & 6 & $5(83.3)$ & $293.2(57.8)$ & $6(100)$ & $479.3(94.5)$ \\
09.00 & 6 & $4(66.6)$ & $250.5(49.4)$ & $5(83.3)$ & $422.4(83.3)$ \\
10.00 & 6 & $2(33.3)$ & $390.5(77.0)$ & $6(100)$ & $363.1(71.6)$ \\
11.00 & 6 & $3(50.0)$ & $250.6(49.4)$ & $4(66.6)$ & $388.7(76.6)$ \\
12.00 & 6 & $2(33.3)$ & $240.0(47.3)$ & $5(83.3)$ & $385.2(75.9)$ \\
13.00 & 6 & $5(83.3)$ & $234.7(46.3)$ & $5(83.3)$ & $290.4(57.2)$ \\
14.00 & 6 & $3(33.3)$ & $123.6(24.3)$ & $5(83.3)$ & $359.6(70.9)$ \\
15.00 & 6 & $1(16.6)$ & $187.0(36.8)$ & $4(66.6)$ & $322.0(63.5)$ \\
16.00 & 6 & $0(0)$ & $0(0)$ & $1(33.3)$ & $383.0(75.4)$ \\
\hline
\end{tabular}

Keterangan: *Angka dalam kurung menunjukkan persentase. Persentase pembentukan benih dihitung berdasarkan rata-rata jumlah ovul per bakal buah sebanyak 507 ovul (rata-rata 10 bakal buah)

Pembentukan benih dalam SH paling tinggi dihasilkan dari penyerbukan pada pukul 08.00 yaitu mencapai $94.5 \%$ dan terus menurun hingga pukul 13.00 , tetapi meningkat kembali hingga pukul 16.00. Hasil pengamatan warna mahkota dan warna permukaan stigma menunjukkan bahwa periode stigma reseptif pada tanaman KE014 yang ditanam dalam SH terjadi antara pukul 07.00-14.00. Dengan demikian diperkirakan penyerbukan tanaman mentimun KE014 yang ditanam dalam SH akan berhasil jika dilakukan antara pukul 07.00-14.00. Nicodemo et al. (2012) melaporkan bahwa di Brasil masa reseptif stigma mentimun yang ditanam dalam green house berlangsung hingga pukul 15.00 .

\section{Pemanfaatan Serbuk Sari Setelah Disimpan dalam Produksi Benih Hibrida Varietas KE014 di Lapangan}

Daya berkecambah serbuk sari segar dari tanaman di lapangan cukup rendah, sebesar $26.45 \%$, dan menurun secara drastis selama dalam penyimpanan, mencapai sekitar $4 \%$ pada $20-30$ HSS dan $<1 \%$ pada 40 HSS (Tabel4). Hasil penelitian ini sejalan dengan hasil penelitian Fariroh (2012) yang menyatakan bahwa serbuk sari mentimun hanya dapat disimpan dalam jangka pendek. Daya berkecambah serbuk sari mentimun varietas KE019 menurun sampai kurang dari $1 \%$ setelah 9 hari disimpan dalam ultra freezer $\left(-79 \pm 2 \quad{ }^{0} \mathrm{C}\right)$. Sebaliknya Sidabutar (2013) menyatakan bahwa serbuk sari mentimun
KE014 yang dikeringkan selama 8 jam dengan $\mathrm{MgCl}_{2}$ mempunyai daya berkecambah $24.60 \%$ pada 56 HSS dalam ultra freezer $\left(-79 \pm 2{ }^{\circ} \mathrm{C}\right)$. Daya simpan serbuk sari yang pendek dalam penelitian ini diduga karena proses pengeringan dengan $\mathrm{MgCl}_{2}$ yang terlalu lama (24 jam).

Tabel 4. Daya berkecambah serbuk sari selama penyimpanan dan perkiraan jumlah serbuk sari yang viabel pada kepala putik

\begin{tabular}{|c|c|c|c|c|}
\hline \multirow{5}{*}{$\begin{array}{c}\text { Lama } \\
\text { Simpan } \\
\text { (HSS) }\end{array}$} & \multirow{5}{*}{$\begin{array}{l}\mathrm{DBSs}^{\mathrm{a}} \\
(\%)\end{array}$} & \multicolumn{3}{|c|}{$\begin{array}{l}\text { Perkiraan Jumlah Serbuk Sari } \\
\text { yang Viabel pada Kepala Putik }\end{array}$} \\
\hline & & $1 \mathrm{x}$ & $2 x$ & $3 x$ \\
\hline & & Usapan & Usapan & Usapan \\
\hline & & $( \pm 2800$ & $( \pm 7300$ & $( \pm 18000$ \\
\hline & & Butir) & Butir) & Butir) \\
\hline 0 & 26.45 & \pm 740 & \pm 1930 & \pm 4760 \\
\hline 20 & 4.05 & \pm 113 & \pm 295 & \pm 730 \\
\hline 30 & 3.89 & \pm 108 & \pm 283 & \pm 700 \\
\hline 40 & 0.80 & \pm 22 & \pm 58 & \pm 144 \\
\hline Keterang & $\begin{array}{l}{ }^{\mathrm{a}} \text { Angk } \\
\text { diikut } \\
\text { nyata } \\
5 \% \mathrm{H} \\
\text { daya b }\end{array}$ & $\begin{array}{l}\text { a pada } \mathrm{k} \\
\text { huruf ya }\end{array}$ & $\begin{array}{l}\text { yang } \\
\text { sama ti } \\
\text { uji DMR' } \\
\text { elah sim } \\
\text { serbuk sar }\end{array}$ & $\begin{array}{l}\text { sama dan } \\
\mathrm{k} \text { berbeda } \\
\text { pada taraf } \\
\text { an, DBSs: }\end{array}$ \\
\hline
\end{tabular}

Perkiraan viabilitas serbuk sari dari bunga segar sebesar $26.45 \%$ jika pen yerbukan dengan sekali usapan kuas terdapat \pm 2800 butir serbuk sari menempel pada stigma, maka jumlah serbuk sari viabel yang menempel pada stigma sekitar 740 butir (Tabel 4). Jika serbuk sari mempunyai daya berkecambah $0.80 \%$ maka perlakuan penyerbukan 1, 2, dan 3 kali 
usapan kuas masing-masing menempelkan serbuk sari viabel pada permukaan stigma sekitar 30, 58, dan 150 butir. Semakin sedikit jumlah serbuk sari viabel yang menempel pada stigma maka jumlah benih per buah semakin rendah.

Keberhasilan penyerbukan dapat diamati 7 hari setelah penyerbukan. Kegagalan penyerbukan dengan serbuk sari yang telah disimpan dapat disebabkan oleh viabilitas serbuk sari yang sudah menurun selama penyimpanan serbuk sari, sehingga tidak terjadi fertilisasi, dan bakal buah tidak berkembang, mengering dan rontok (Gambar 2a). Kegagalan penyerbukan karena tingginya curah hujan menyebabkan buah yang mulai berkembang membusuk dan akhirnya rontok (Gambar 2b), sementara jika penyerbukan berhasil bakal buah akan terus membesar (Gambar 2c).
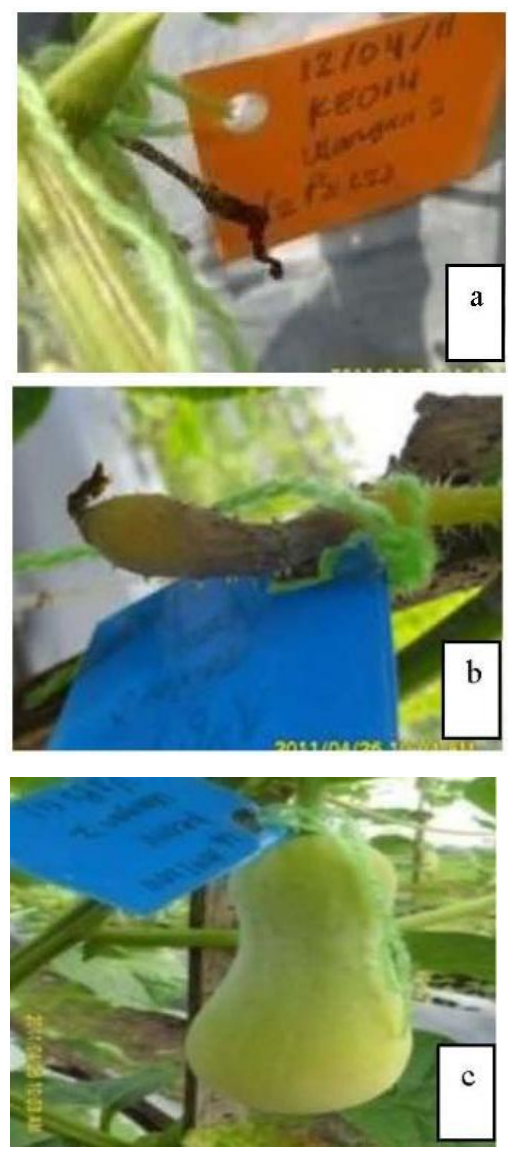

Gambar 2. Perkembangan buah tanaman mentimun KE014: a. Bunga yang mengering setelah penyerbukan, $b$. Buah muda yang membusuk, c. Buah yang berkembang 10 hari setelah penyerbukan
Pada penelitian di lapangan perlakuan kombinasi lama simpan serbuk sari dan teknik penyerbukan berpengaruh terhadap pembentukan buah dan pembentukan benih. Penyerbukan dengan menggunakan serbuk sari segar (kontrol) menghasilkan pembentukan buah mencapai 54.64\%. Pembentukan buah tertinggi dari penggunaan serbuk sari yang telah disimpan diperoleh dari perlakuan 20 HSS + 1 kali usapan kuas yaitu sebesar $42.42 \%$ (Tabel 5). Pada Terminalia paniculata persentase pembentukan buah dari serbuk sari dengan viabilitas sebesar $>90 \%$ sebesar $82 \%$ dan serbuk sari dengan viabilitas $<5 \%$ tidak menghasilkan buah sama sekali (Tangaraja dan Ganesan, 2008). Rendahnya pembentukan buah dalam penelitian ini diduga karena rendahnya viabilitas serbuk sari.

Benih yang terbentuk menggunakan serbuk sari segar mencapai 59.26\%, sedangkan persentase pembentukan benih tertinggi diperoleh dari perlakuan kombinasi lama simpan $20 \mathrm{HSS}+3$ kali usapan kuas yaitu sebesar 25.26\% (Tabel 5). Keberhasilan reproduksi pada tanaman diartikan sebagai proporsi jumlah ovul yang berkembang sempurna menjadi biji. Keberhasilan reproduksi dengan menggunakan serbuk sari dari bunga segar yaitu sebesar 0.3238 dari potensi yang dimilikinya artinya bahwa dari jumlah ovul sebanyak 10000 ovul yang diproduksi tanaman, yang akhirnya berkembang menjadi benih yang viabel sebanyak 3238 buah (Tabel 5). Untuk serbuk sari yang telah disimpan nilai keberhasilan reproduksi tertinggi pada perlakuan $20 \mathrm{HSS}+1$ usapan kuas yaitu sebesar 0.0949 atau $9.49 \%$ dari potensinya (Tabel 5).

Keberhasilan reproduksi tertinggi dari penggunaan serbuk sari yang telah disimpan 20 HSS + 1 usapan kuas yaitu sebesar 29.29\% dan keberhasilan reproduksi terendah dari perlakuan 40 HSS + 2 kali usapan kuas sebesar $12.82 \%$. Penggunaan serbuk sari yang sudah disimpan >20 HSS berpotensi menghasilkan benih sekitar 12.82-29.29\% dengan rata-rata $19.89 \%$. Data ini menunjukkan bahwa viabilitas serbuk sari mempengaruhi keberhasilan reproduksi dalam produksi benih yang kaitanya dengan jumlah serbuk sari yang mampu membuahi sel telur dan menghasilkan biji bernas. 


\section{J. Hort. Indonesia 5(2):104-117. Agustus 2014.}

Tabel 5. Pengaruh perlakuan kombinasi lama simpan serbuk sari dan teknik penyerbukan terhadap persentase pembentukan buah, jumlah benih/buah, keberhasilan reproduksi dan persentase proposi keberhasilan reproduksi di lapang

\begin{tabular}{lcccc}
\hline \multicolumn{1}{c}{ Perlakuan kombinasi } & PB $^{\text {a }(\%)}$ & $\begin{array}{c}\Sigma \text { Benih Buah }^{-1} \\
(\mathrm{PBi})(\%)\end{array}$ & KR & $\begin{array}{c}\text { Proporsi KRSs } \\
\text { terhadap KRk }(\%)\end{array}$ \\
\hline P0: Bunga segar (Kontrol) & $54.64 \mathrm{a}$ & $300.4 \mathrm{a}(59.26)$ & 0.3238 & 100 \\
P1: 20 HSS + 1 UK & $42.42 \mathrm{ab}$ & $113.4 \mathrm{~b}(22.36)$ & 0.0949 & 29.29 \\
P2: 20 HSS + 2 UK & $35.50 \mathrm{bc}$ & $92.1 \mathrm{~b}(18.16)$ & 0.0645 & 19.91 \\
P3: 20 HSS + 3 UK & $34.81 \mathrm{bc}$ & $128.1 \mathrm{~b}(25.26)$ & 0.0879 & 27.16 \\
P4: 30 HSS + 1 UK & $27.26 \mathrm{bc}$ & $85.6 \mathrm{~b}(16.89)$ & 0.0460 & 14.20 \\
P5: 30 HSS + 2 UK & $26.39 \mathrm{bc}$ & $121.5 \mathrm{~b}(23.96)$ & 0.0632 & 19.52 \\
P6: 30 HSS + 3 UK & $21.23 \mathrm{c}$ & $116.1 \mathrm{~b}(22.89)$ & 0.0486 & 15.01 \\
P7: 40 HSS + 1 UK & $37.89 \mathrm{bc}$ & $95.0 \mathrm{~b}(18.73)$ & 0.0710 & 21.92 \\
P8: 40 HSS + 2 UK & $24.25 \mathrm{c}$ & $86.8 \mathrm{~b}(17.13)$ & 0.0415 & 12.82 \\
P9: 40 HSS + 3 UK & $32.13 \mathrm{bc}$ & $98.2 \mathrm{~b}(19.37)$ & 0.0622 & 19.21 \\
\hline & \multicolumn{3}{c}{ Rata - rata } \\
\hline
\end{tabular}

Keterangan: ${ }^{a}$ Angka yang diikuti huruf sama pada kolom yang sama tidak berbeda nyata berdasarkan DMRT pada taraf 5\%. HSS: hari simpan serbuk sari,UK: usapan kuas, PB: pembentukan buah, PBi: pembentukan benih, KR: keberhasilan reproduksi. KRSs: keberhasilan reproduksi dengan menggunakan serbuk sari yang telah disimpan, KRk: keberhasilan reproduksi dengan menggunakan serbuk sari segar. Angka yang di dalam kurung adalah persentase pembentukan buah. Rata-rata dihitung dari perlakuan serbuk sari yang telah disimpan.

Tabel 6. Pengaruh perlakuan kombinasi lama simpan serbuk sari dan teknik penyerbukan terhadap mutu benih di lapangan

\begin{tabular}{lcccc}
\hline $\begin{array}{l}\text { Perlakuan } \\
\text { kombinasi }\end{array}$ & $\begin{array}{c}\mathrm{DB}^{\mathrm{a}} \\
(\%)\end{array}$ & $\begin{array}{c}\mathrm{PTM}^{\mathrm{a}} \\
(\%)\end{array}$ & $\begin{array}{c}\mathrm{BKKN}^{\mathrm{a}} \\
(\mathrm{g})\end{array}$ & $\begin{array}{c}\text { Bobot } \\
100^{\mathrm{a}} \\
\text { Butir } \\
(\mathrm{g})\end{array}$ \\
\hline $\begin{array}{l}\text { P0: Bunga segar } \\
\text { (Kontrol) }\end{array}$ & 91.11 & 96.44 & 0.371 & 2.531 \\
P1:20HSS+1UK & 89.77 & 98.66 & 0.367 & 2.809 \\
P2: 20HSS+2UK & 89.11 & 95.77 & 0.442 & 2.878 \\
P3: 20HSS+3UK & 83.55 & 99.55 & 0.376 & 2.550 \\
P4:30HSS+1UK & 92.89 & 96.44 & 0.423 & 2.753 \\
P5:30HSS+2UK & 87.33 & 96.00 & 0.371 & 2.558 \\
P6:30HSS+3UK & 94.44 & 97.77 & 0.425 & 2.543 \\
P7:40HSS+1 UK & 93.11 & 97.55 & 0.431 & 2.419 \\
P8:40HSS+2UK & 89.33 & 98.66 & 0.376 & 2.564 \\
P9:40HSS+3UK & 96.66 & 100 & 0.407 & 3.090 \\
\hline Keterangan: $\begin{array}{c}\text { angka yang diikuti huruf sama pada } \\
\text { kolom yang sama tidak berbeda nyata }\end{array}$ \\
berdasarkan DMRT pada taraf 5\%. HSS: \\
kari simpan serbuk sari, UK: usapan \\
PTas, DB: daya berkecambah benih, \\
BKKN: berat kering kecambah normal.
\end{tabular}

Mutu benih (DB, PTM, BKKN, bobot 100 butir) yang dihasilkan dari penyerbukan dengan menggunakan perlakuan kombinasi lama simpan dengan teknik penyerbukan tidak berbeda nyata dengan penyerbukan menggunakan serbuk sari sari segar (kontrol) (Tabel 6). Hal ini terjadi karena sudah dilakukan pemilahan terlebih dahulu, hanya biji bernas yang dikategorikan sebagai benih dan diuji mutunya.

Benih dari P3 dan P5 (perlakuan kombinasi 20 HSS + 3 kali usapan kuas dan 30 HSS +2 kali usapan kuas) mempunyai daya berkecambah yang tidak memenuhi standar operasional perusahaan dalam penetapan batas minimum daya berkecambah benih $>88.00 \%$ (Tabel 6). Potensi tumbuh maksimum berkisar 95.77-100\%. Bobot kering kecambah normal yang dihasilkan berkisar 0.367-0.442 g. Sementara, bobot 100 butir pada percobaan di lapangan mempunyai bobot berkisar antara 2.41-3.09 g (Tabel 6), yang semuanya memenuhi standar minimum perusahaan sebesar $2.754 \mathrm{~g}$.

Hasil korelasi antar peubah menunjukkan bahwa daya berkecambah serbuk sari berkorelasi dengan persentase pembentukan buah dan pembentukan benih dengan nilai korelasi masing-masing sebesar $0.9155^{* *}$ dan $0.9225 * *$ (Tabel 7). Persentase pembentukan benih juga berkorelasi dengan persentase pembentukan buah $\left(\mathrm{r}=0.855^{* *}\right)$. Data ini memberi indikasi bahwa semakin tinggi daya berkecambah serbuk sari maka pembentukan buah dan pembentukan benih di lapangan akan semakin meningkat juga. Semakin tinggi pembentukan buahnya maka pembentukan benih juga akan semakin meningkat. 
Tabel 7. Rekapitulasi nilai korelasi antar peubah pengamatan di lapangan

\begin{tabular}{cccc}
\hline \multirow{2}{*}{$\begin{array}{c}\text { Komponen } \\
\text { peubah }\end{array}$} & \multicolumn{3}{c}{ Komponen peubah } \\
\cline { 2 - 3 } & $\begin{array}{c}\text { DB } \\
\text { serbuk } \\
\text { sari }\end{array}$ & PB (\%) & PBi (\%) \\
\hline
\end{tabular}

\begin{tabular}{|c|c|c|c|}
\hline $\begin{array}{l}\text { DB serbuk } \\
\text { sari }\end{array}$ & - & & \\
\hline PB $(\%)$ & $0.9155^{* *}$ & - & \\
\hline PBi (\%) & $0.9225^{* *}$ & $0.855^{* *}$ & - \\
\hline $\begin{array}{l}\text { Bobot } 100 \text { Butir } \\
\text { (g) }\end{array}$ & $-0.2392^{\mathrm{tn}}$ & $-0.0455^{\text {tn }}$ & $-0.1111^{\mathrm{tn}}$ \\
\hline
\end{tabular}

\section{Pemanfaatan Serbuk Sari Setelah Disimpan dalam Produksi Benih Hibrida Varietas KE014 di Screen House}

Lot serbuk sari dari bunga segar pada tanaman di SH mempunyai daya berkecambah sebesar 32\% (Tabel 8), pada 7 dan 14 HSS daya berkecambah serbuk sari menurun hingga mempunyai daya berkecambah sebesar 9\% hingga masa simpan 28 HSS mempunyai daya berkecambah sebesar $4.86 \%$ (Tabel 9). Menurut Perveen dan Ali (2011) suhu $-30{ }^{\circ} \mathrm{C}$ cukup memadai untuk penyimpanan serbuk sari Cucurbitaceae dalam jangka panjang dan tetap mempunyai daya berkecambah paling tinggi dibandingkan dengan penyimpanan pada suhu $4{ }^{\circ} \mathrm{C}$ (kulkas). Khan dan Perveen (2010) melaporkan bahwa serbuk sari Citrullus lanatus L. yang dikeringkan menggunakan silika gel dan di vakum atau pengeringan beku pada suhu $-60{ }^{0} \mathrm{C}$ masih mempunyai viabilitas $51.50 \%$ pada 48 minggu setelah simpan. Menurut Fariroh et al. (2011) penyimpanan serbuk sari mentimun pada suhu rendah dalam ultra freezer $\left(-79 \pm 2{ }^{\circ} \mathrm{C}\right)$ dapat mempertahankan viabilitas serbuk sari mentimun di atas 1\% hingga 12 minggu setelah simpan. Penurunan viabilitas serbuk sari yang cukup besar dalam penelitian ini karena viabilitas awal sebelum disimpan yang rendah. Hal ini diduga karena metode pengeringan yang terlalu lama (24 jam pengeringan anthera dan 24 jam pengeringan serbuk sari setelah ekstraksi).

Viabilitas serbuk sari dari bunga segar sebesar $32 \%$. Jika penyerbukan dengan satu kali usapan kuas dapat menempelkan serbuk sari sekitar 2800, maka jumlah serbuk sari yang viabel sebanyak 918 butir. Serbuk sari dengan dengan daya berkecambah antara 9.65$9.71 \%$ setara dengan \pm 270 butir serbuk sari viabel (Tabel 8).

Berdasarkan hasil penentuan masa reseptif stigma penyerbukan silang untuk penelitian di SH dilakukan antara pukul 07.00 hingga pukul 14.00. Persentase pembentukan buah pada penyerbukan menggunakan serbuk sari segar (kontrol) tidak berbeda nyata dengan perlakuan kombinasi lama simpan serbuk sari dan teknik penyerbukan. Hal ini diduga karena suhu dan kelembapan di dalam SH yang tidak berfluktuasi dan tanaman tidak terkena hujan secara langsung, sehingga tidak mengganggu proses pembentukan buah. Buah yang dapat dipanen dari penyerbukan menggunakan serbuk sari segar (kontrol) sebesar 73.56\% (Tabel 9). Persentase pembentukan buah tertinggi dengan menggunakan perlakuan kombinasi lama simpan dan teknik penyerbukan diperoleh dari perlakuan 7 HSS +2 kali usapan kuas dan terendah pada perlakuan 28 HSS + 2 kali usapan kuas (Tabel 9).

Hasil yang diperoleh dari perlakuan kombinasi lama simpan serbuk sari dan teknik penyerbukan berpengaruh terhadap pembentukan benih. Persentase pembentukan benih pada penyerbukan menggunakan serbuk sari segar sebesar $80.7 \%$, dan perlakuan kombinasi yang menghasilkan persentase pembentukan benih tertinggi adalah perlakuan 28 HSS + 3 kali usapan kuas sebesar $35.7 \%$ (Tabel 9). Keberhasilan reproduksi tertinggi untuk serbuk sari yang telah disimpan yaitu pada perlakuan 7 HSS +2 kali usapan kuas sebesar 0.1501. Keberhasilan reproduksi dari serbuk sari yang telah disimpan sebesar 10.60$25.29 \%$ dengan rata-rata sebesar $18.89 \%$.

Daya berkecambah benih mentimun yang dihasilkan dalam SH berkisar antara 64-91\%, tidak semuanya memenuhi standar operasional perusahaan untuk produksi benih hibrida mentimun. Rendahnya daya berkecambah benih diduga karena pengujian dilakukan langsung setelah ekstraksi dan pengeringan benih. Hanya perlakuan $14 \mathrm{HSS}+2$ kali usapan kuas, 28 HSS + 2 kali usapan kuas dan perlakuan 28 HSS + 3 kali usapan kuas mempunyai daya berkecambah benih di atas standar operasional perusahaan (Tabel 10). Potensi tumbuh maksimum berkisar antara 69-96\%. Bobot 


\section{J. Hort. Indonesia 5(2):104-117. Agustus 2014.}

kering kecambah normal yang diperoleh berkisar antara 0.299-0.423 g maka sebagian besar memenuhi standar operasional perusahaan sebesar $2.756 \mathrm{~g}$, kecuali perlakuan dengan menggunakan bunga segar (kontrol) (Tabel 10). Hal ini diduga berkaitan dengan jumlah benih yang terbentuk perbuah.

Tabel 8. Daya berkecambah serbuk sari selama penyimpanan dan perkiraan jumlah serbuk sari yang viabel pada kepala putik

\begin{tabular}{clccc}
\hline \multirow{2}{*}{ Lama simpan (HSS) } & & \multicolumn{3}{c}{ Perkiraan Jumlah Serbuk Sari yang Viabel pada Kepala Putik } \\
\cline { 3 - 5 } & DBSs $^{\mathrm{a}}(\%)$ & $\begin{array}{c}\text { 1x Usapan } \\
( \pm 2800 \text { Butir })\end{array}$ & $\begin{array}{c}\text { 2x Usapan } \\
( \pm 7300 \text { Butir })\end{array}$ & $\begin{array}{c}3 \text { 3x Usapan } \\
( \pm 18 \text { 000 Butir })\end{array}$ \\
\hline 0 & $32.00 \mathrm{a}$ & \pm 896 & \pm 2336 & \pm 5760 \\
7 & $9.71 \mathrm{~b}$ & \pm 271 & \pm 708 & \pm 1747 \\
14 & $9.65 \mathrm{~b}$ & \pm 270 & \pm 704 & \pm 1737 \\
21 & $6.98 \mathrm{bc}$ & \pm 195 & \pm 509 & \pm 1256 \\
28 & $4.86 \mathrm{c}$ & \pm 136 & \pm 354 & \pm 874.8 \\
\hline
\end{tabular}

Keterangan: ${ }^{a}$ Angka pada kolom yang sama dan diikuti huruf yang sama tidak berbeda nyata berdasarkan uji DMRT pada taraf 5\%. HSS: hari setelah simpan, DBSs: Daya berkecambah serbuk sari

Tabel 9. Pengaruh perlakuan kombinasi lama simpan serbuk sari dan teknik penyerbukan terhadap persentase pembentukan buah, jumlah benih/buah, keberhasilan reproduksi dan persentase proporsi keberhasilan reproduksi.

\begin{tabular}{lcccc}
\hline \multicolumn{1}{c}{ Perlakuan kombinasi } & $\mathrm{Pb}^{\mathrm{a}(\%)}$ & $\begin{array}{c}\sum \text { Benih Buah }^{-1} \\
(\mathrm{PBi})(\%)\end{array}$ & KR & $\begin{array}{c}\text { Proporsi KRSs } \\
\text { terhadap KRk }(\%)\end{array}$ \\
\hline P0: Bunga segar (kontrol) & $73.5 \mathrm{a}$ & $409.1 \mathrm{a}(80.6)$ & 0.5936 & 100.00 \\
P1: 7 HSS + 1 UK & $49.4 \mathrm{ab}$ & $92.4 \mathrm{~b}(18.2)$ & 0.0902 & 15.20 \\
P2: 7 HSS + 2 UK & $63.9 \mathrm{ab}$ & $118.9 \mathrm{~b}(23.4)$ & 0.1501 & 25.29 \\
P3: 7 HSS + 3 UK & $43.7 \mathrm{ab}$ & $155.6 \mathrm{~b}(30.6)$ & 0.1341 & 22.59 \\
P4: $14 \mathrm{HSS}+1 \mathrm{UK}$ & $44.8 \mathrm{ab}$ & $99.1 \mathrm{~b}(19.5)$ & 0.0876 & 14.75 \\
P5: $14 \mathrm{HSS}+2 \mathrm{UK}$ & $47.9 \mathrm{ab}$ & $140.1 \mathrm{~b}(27.6)$ & 0.1325 & 22.32 \\
P6: $14 \mathrm{HSS}+3 \mathrm{UK}$ & $48.1 \mathrm{ab}$ & $135.7 \mathrm{~b}(26.7)$ & 0.1290 & 21.73 \\
P7: $21 \mathrm{HSS}+1 \mathrm{UK}$ & $42.2 \mathrm{ab}$ & $128.5 \mathrm{~b}(25.3)$ & 0.1070 & 18.03 \\
P8: $21 \mathrm{HSS}+2 \mathrm{UK}$ & $38.6 \mathrm{ab}$ & $132.6 \mathrm{~b}(26.1)$ & 0.1012 & 17.05 \\
P9: $21 \mathrm{HSS}+3 \mathrm{UK}$ & $43.3 \mathrm{ab}$ & $139.9 \mathrm{~b}(27.5)$ & 0.1196 & 20.15 \\
P10: $28 \mathrm{HSS}+1 \mathrm{UK}$ & $35.6 \mathrm{~b}$ & $117.7 \mathrm{~b}(23.2)$ & 0.0823 & 13.86 \\
P11: $28 \mathrm{HSS}+2 \mathrm{UK}$ & $30.6 \mathrm{~b}$ & $104.0 \mathrm{~b}(20.5)$ & 0.0629 & 10.60 \\
P12: $28 \mathrm{HSS}+3 \mathrm{UK}$ & $41.7 \mathrm{ab}$ & $180.9 \mathrm{~b}(35.6)$ & 0.1490 & 25.10 \\
\hline
\end{tabular}

Keterangan: ${ }^{a}$ Angka yang diikuti huruf sama pada kolom yang sama tidak berbeda nyata berdasarkan DMRT pada taraf 5\%. HSS: hari simpan serbuk sari, UK: usapan kuas, PB: pembentukan buah, PBi: pembentukan benih, KR: keberhasilan reproduksi. KRSs: keberhasilan reproduksi dengan menggunakan serbuk sari yang telah disimpan, KRk: keberhasilan reproduksi dengan menggunakan serbuk sari segar. Angka yang didalam kurung adalah persentase pembentukan buah. Rata-rata dihitung dari perlakuan serbuk sari yang telah disimpan.

Hasil korelasi menunjukkan bahwa karakter peubah yang berkorelasi nyata dengan daya berkecambah serbuk sari yaitu pembentukan buah dan pembentukan benih dengan masing-masing nilai korelasi yaitu $0.6705 * *$ dan $0.9517 * *$ serta karakter peubah antara pembentukan buah dengan pembentukan benih $\left(\mathrm{r}=0.677^{* *}\right)$ (Tabel 11). Data ini menunjukkan bahwa semakin tinggi daya berkecambah serbuk sari maka pembentukan buah dan pembentukan benih akan semakin meningkat juga. 
Tabel 10. Pengaruh perlakuan kombinasi lama simpan serbuk sari dan teknik penyerbukan terhadap mutu benih di SH

\begin{tabular}{lcccr}
\hline \multicolumn{1}{c}{ Perlakuan kombinasi } & $\mathrm{DB}^{\mathrm{a}}$ & $\mathrm{PTM}^{\mathrm{a}}(\%)$ & BKKN $^{\mathrm{a}}(\mathrm{g})$ & $\begin{array}{c}\text { Bobot } 100^{\mathrm{a}} \\
\text { butir }(\mathrm{g})\end{array}$ \\
\hline P0: Bunga segar (kontrol) & 83.11 & 89.33 & 0.406 & 2.639 \\
P1: 7 HSS + 1 UK & 84.44 & 94.66 & 0.382 & 3.003 \\
P2: 7 HSS + 2 UK & 71.55 & 76.00 & 0.420 & 2.931 \\
P3: 7 HSS + 3 UK & 84.89 & 91.78 & 0.299 & 2.978 \\
P4: 14 HSS + 1 UK & 64.44 & 68.89 & 0.404 & 2.902 \\
P5: 14 HSS + 2 UK & 88.89 & 90.22 & 0.368 & 2.986 \\
P6: 14 HSS + 3 UK & 72.22 & 81.33 & 0.353 & 3.276 \\
P7: 21 HSS + 1 UK & 82.44 & 88.00 & 0.375 & 2.991 \\
P8: 21 HSS + 2 UK & 73.33 & 87.55 & 0.392 & 3.058 \\
P9: 21 HSS + 3 UK & 84.67 & 86.00 & 0.395 & 3.053 \\
P10: 28 HSS + 1 UK & 76.89 & 86.89 & 0.374 & 3.100 \\
P11: 28 HSS + 2 UK & 90.67 & 95.78 & 0.403 & 2.979 \\
P12: 28 HSS + 3 UK & 89.77 & 92.00 & 0.423 & 2.995 \\
\hline Ke
\end{tabular}

Keterangan: ${ }^{a}$ Angka yang diikuti hurufsama pada kolom yang sama tidak berbeda nyata berdasarkan DMRT pada taraf 5\%. DB:daya berkecambah benih, PTM: potensi tumbuh maksimum, BKKN: berat kering kecambah normal

Tabel 11. Rekapitulasi nilai korelasi antar peubah pengamatan di SH

\begin{tabular}{lccc}
\hline \multirow{2}{*}{ Komponen peubah } & \multicolumn{3}{c}{ Komponen peubah } \\
\cline { 2 - 4 } & DB serbuk sari & PB $(\%)$ & PBi (\%) \\
\hline DB serbuk sari & - & & \\
PB (\%) & $0.6705^{* *}$ & - & - \\
PBi (\%) & $0.9517^{* *}$ & $0.677^{* *}$ & $-0.8003^{* *}$ \\
Bobot 100 Butir $(\mathrm{g})$ & $-0.2493 \mathrm{tn}$ & $-0.5169^{*}$ &
\end{tabular}

Keterangan: *berbeda nyata. **berbeda sangat nyata. ${ }^{\text {tn }}$ tidak berbeda nyata. PBi: pembentukan buah PBi: pembentukan benih, DB: daya berkecambah

Persentase pembentukan buah berkorelasi negatif dengan bobot 100 butir benih $(\mathrm{r}=-$ $0.5169)$ dan pembentukan benih $(r=0.8003)$ (Tabel 11) yang artinya semakin tinggi persentase pembentukan buah maka semakin kecil bobot benih yang akan dihasilkan. Pada proses budidaya produksi benih hibrida tanaman mentimun ada batasan dan aturan berapa banyak buah yang akan diserbuki untuk menghasilkan bobot benih yang sesuai dengan standar operasional perusahaan.

\section{KESIMPULAN}

Masa reseptif stigma tanaman betina mentimun varietas KE014 terjadi antara pukul 07.00-13.00. Serbuk sari yang telah di simpan 7-28 HSS mempunyai viabilitas sekitar 4.869.71\%, sementara yang di simpan 20-40 HSS berkisar $0.80-4.05 \%$.
Serbuk sari yang telah disimpan menurunkan persentase pembentukan buah dan benih mentimun (Cucumis sativus L.) varietas KE014 di lapangan, sedangkan di screen house hanya menurunkan persentase pembentukan benih. Pembentukan buah dan benih di lapangan masing-masing berkisar $21.23-42.42 \%$ dan $16.89-25.26 \%$, sedangkan dalam SH masing-masing berkisar 30.69$63.98 \%$ dan $18.22-35.68 \%$.

Keberhasilan reproduksi dari penggunaan serbuk sari yang telah disimpan pada penelitian di lapangan berkisar 12.82-29.29\% dari kontrol dengan rata-rata sebesar 19.89\%. Potensi keberhasilan reproduksi di SH sebesar 10.60-25.29\% dengan rata-rata sebesar $18.89 \%$. Mutu benih yang dihasilkan dari serbuk sari yang telah disimpan memenuhi persyaratan mutu benih yang layak diedarkan. Daya berkecambah benih yang dihasilkan pada pertanaman di lapangan berkisar anatara 83$96 \%$, potensi tumbuh maksimum berkisar 
antara 96-100\%, bobot kering kecambah normal berkisar antara 0.367-0.442 g dengan bobot 100 butir antara 2.41-3.09 $\mathrm{g}$ dan pertanaman di $\mathrm{SH}$ daya berkecambah benih berkisar antara 64-91\%, potensi tumbuh maksimum berkisar antara 69.00-96.00\%, bobot kering kecambah normal 0.299-0.423 g 64.44-90.67\% dengan bobot 100 butir antara 2.64-3.27 g.

\section{UCAPAN TERIMA KASIH}

Penulis menyampaikan terima kasih kepada PT East West Indonesia yang mendanai dan memfasilitasi selama penelitian berlangsung.

\section{DAFTAR PUSTAKA}

Agbagwa, I.O., C.N. Benjamin, I.M. Stephen. 2007. Floral biology, breeding system, and pollination ecology of Cucurbita moschata (Dutch.ax Lam) Duch. Ex Poir. varieties (Cucurbitaceae) from parts of the Niger Delta, Nigeria. Turk J Bot. 31: 451-458.

Badan Pusat Statistik. 2011. Produksi sayuran di Indonesia 1997-2011. http://www.bps. go.id/tab_sub/view.php?tabel=1\&daftar $=1 \& i d \_s u b y e k=55 \&$ notab $=20 \quad[19 \quad$ Nov 2011].

Delaplane, K.S., D.F. Meyer. 2009. Cucumber. http://ag.udel.edu/enwc/faculty/dmcaron/P ollination/Cucumber.html. [12 Des 2011].

Fariroh, I. 2012. Pengaruh pengeringan, media pengujian, waktu panen dan kondisi ruang simpan terhadap viabilitas serbuk sari mentimun (Cucumis sativus L). Skripsi. Institut Pertanian Bogor. Bogor.

Fariroh, I., E.R. Palupi, S.W. Dudin. 2011. Media Perkecambahan dan Kondisi Ruang Simpan Serbuk Sari Mentimun (Cucumis sativus L.). Prosiding Seminar Nasional Perhimpunan Hortikultura Indonesia. Perhimpunan Hortikultura Indonesia dan Institut Pertanian Bogor. Lembang. 431-438.
Kelly, J.K., A. Rasch, S. Kalisz. 2002. A method to estimate pollen viability from pollen size variation. American Journal of Botany. 89(6): 1021-1023.

Nascimento, V.M., A.C. Torres, L.B. Lima. 2009. Pollen viability in hybrid seed production of eggplant under tropical conditions. in Internatioal Society for Horticulture Science symposium IX www.actahort.org/books/607_4.htm. [ 31 Oktober 2013].

Neppi, M., E. Paccini. 1993. Pollination, pollen viabillity and pistil receptivity in Cucurbita peppo. Annals of Botany. 75: 527-536.

Nicodemo, D., E.B. Malheiros, Dde Jong, R.H.N. Couto. 2012. Floral biology of greenhouse grown aodai cucumber plants (Cucumis sativus L.). Cientifica (Jaboti Cabal). 40.1: 41-46.

Perveen, A., S. Ali. 2011. Pollen germination capacity and maintenance of pollen in Praecitrullus fistulosus (stocks) pangola (Cucurbitaceae). Pak. J. Bot. 3(1): 4750 .

Sidabutar, R.M. 2013. Pengeringan dan penyimpanan serbuk sari mentimun (Cucumis sativus L.) serta pemanfaatannya dalam produksi benih hibrida. Skripsi. Institut Pertanian Bogor. Bogor.

Sukma, D., A. Setiawati. 2010. Pengaruh waktu dan aplikasi pupuk daun terhadap pertumbuhan dan pembungaan anggrek Dendrobium 'Tong Chai Gold'. J. Hort. Indonesia. 1(2): 96-103.

Tangaraja, A., V. Ganesan. 2008. Studies on the pollen biology of Terminalia paniculata Roth (Combretaceae). African Journal of Plant Science. 2(12): 140146.

Tay, D. 2013. Vegetable hybrid seed production. http://www.Osu.edu/content/ seed_trade_production_technology.pdf. [31 Okt 2013]. 
Zaman, M.R. 2006. Pollen germination, viability and tube growth in fourteen cultivated and wild species of cucurbit grown in Bangladesh. J. Life Earth Sci. 1(2): 1-7. 